\title{
A heart in an eggshell
}

\author{
Mumun Sinha, ${ }_{1}^{1}$ Niraj Nirmal Pandey, ${ }^{2}$ Rengarajan Rajagopal, ${ }^{3}$ Sanjeev Kumar ${ }^{4}$
}

${ }^{1}$ All India Institute of Medical Sciences Centre, Cardiovascular Radiology and Endovascular Interventions, New Delhi, India ${ }^{2}$ Cardiovascular Radiology and Endovascular Intervention, All India Institute of Medical Sciences, New Delhi, Delhi, India ${ }^{3}$ All India Institute of Medical Sciences Cardio-Thoracic Sciences Centre, New Delhi, Delhi, India Sciences, New Delhi, India

\section{Correspondence to} sanjeevradio@gmail.com

Accepted 3 December 2018 Sciences Cardio-Thoracic

${ }^{4}$ All India Institute of Medical

Dr Sanjeev Kumar,

\section{DESCRIPTION}

A 60-year-old man presented to the cardiology outpatient department with gradually progressive shortness of breath and cough associated with palpitations on exertion for the past 2 years. On physical examination, there was presence of bilateral pitting pedal oedema. Sonographic examination revealed mild hepatomegaly, dilated inferior vena cava (IVC), hepatic veins and moderate ascites.

Frontal chest radiograph showed the presence of pericardial calcifications and normal cardiac size (figure 1A). A transthoracic echocardiography was performed which showed presence of thickened and calcified pericardium, biatrial dilatation with tubular ventricles, interventricular septal bounce and dilated IVC with absence of inspiratory collapse. There was mild mitral and tricuspid regurgitation with normal biventricular ejection fractions. CT angiography (CTA) confirmed the presence of nodular, chunky and plaque-like calcification almost entirely encasing the heart (figure 1B). In some locations, the calcification was seen to penetrate into the underlying myocardium (figure 1C).

This rare configuration of calcific pericarditis has been previously referred to as 'egg shell calcification of the heart', although none of the previous reports have demonstrated calcifications penetrating into the underlying myocardium. ${ }^{1}{ }^{2}$ Transthoracic echocardiography is commonly the initial imaging modality in such cases, usually for the assessment of myocardial function in patients with symptoms of constrictive physiology. However, it is not highly accurate for assessment of pericardial thickening. Also, evaluation of pericardial thickening anterior to the right ventricle and near the atrioventricular groove is inadequate on account of limited acoustic window. CTA or cardiac MRI can confirm the diagnosis in equivocal cases. Both the modalities offer distinct advantages over echocardiography by providing a larger field of view and better soft tissue

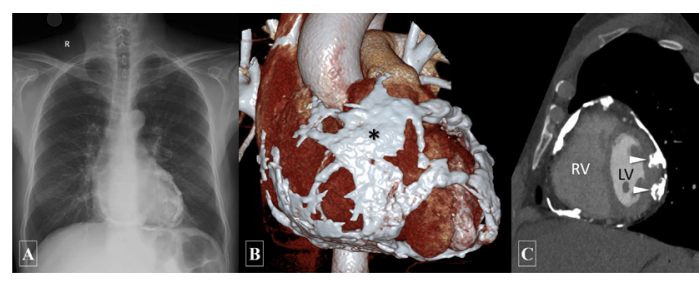

(c) BMJ Publishing Group Limited 2019. No commercial re-use. See rights and permissions. Published by BMJ.

To cite: Sinha M, Pandey NN, Rajagopal R, et al. BMJ Case Rep 2019;12:e227968.

doi:10.1136/bcr-2018-

227968
Figure 1 Frontal chest radiograph (A) shows normal cardiac size with pericardial calcifications. Volume rendered image (B) and short axis reconstruction (C) of $\mathrm{CT}$ angiography reveals plaque-like calcifications almost entirely encasing the heart (asterisk). Few chunky and irregular calcifications are seen penetrating the underlying myocardium (arrowheads). contrast along with excellent depiction of the pericardial thickening and the associated characteristic morphology of the central cardiovascular structures, such as tubular deformities of the ventricles, leftward deviation of septum and systemic venous dilatation. While MRI is better at tissue characterisation and can provide reliable differentiation between restrictive cardiomyopathy and constrictive pericarditis, the location, extent and severity of the calcification is best demonstrated by CTA. ${ }^{3}$

The definitive management in this case would include a surgical pericardiectomy. However, in cases with heavily calcified and firmly adherent pericardium, there is higher surgical risk, chances of incomplete pericardial resection and increased possibility of poor haemodynamic outcomes following surgery. ${ }^{1}$ The patient in question was offered surgical pericardiectomy and the associated risks explained to him; however, the patient refused cardiac surgery. The patient was therefore put on conservative management and is now on regular follow-up with outpatient clinic visits; however at 1-month follow-up, no significant improvement in symptoms was seen.

\section{Learning points}

- 'Egg shell calcification of the heart' is a rare manifestation of calcified pericarditis where almost the entire heart is encased in plaque-like pericardial calcification.

- Evaluation of pericardial thickening anterior to the right ventricle and near the atrioventricular groove is limited on transthoracic echocardiography; the location, extent and severity of the calcification is best demonstrated by CT angiography.

- Surgical pericardiectomy in cases with heavily calcified and firmly adherent pericardium has poor prognosis including chances of incomplete pericardial resection and poor postsurgical haemodynamic outcomes.

Contributors MS, NNP, RR and SK have participated sufficiently in the conception of the idea, development of the intellectual content, design, writing and final approval of the manuscript.

Funding The authors have not declared a specific grant for this research from any funding agency in the public, commercial or not-for-profit sectors.

Competing interests None declared.

Patient consent for publication Obtained.

Provenance and peer review Not commissioned; externally peer reviewed.

\section{REFERENCES}

1 Vijayvergiya R, Vadivelu R, Mahajan $S$, et al. Eggshell calcification of the heart in constrictive pericarditis. World J Cardiol 2015;7:579-82. 


\section{Images in...}

2 Song BG, Kang GH, Park YH, et al. Heart in an eggshell calcification: idiopathic calcific constrictive pericarditis. Cardiol Res 2011;2:310-2.

3 Wang ZJ, Reddy GP, Gotway MB, et al. CT and MR imaging of pericardial disease. Radiographics 2003;23:S167-80.

Copyright 2018 BMJ Publishing Group. All rights reserved. For permission to reuse any of this content visit

https://www.bmj.com/company/products-services/rights-and-licensing/permissions/

BMJ Case Report Fellows may re-use this article for personal use and teaching without any further permission.

Become a Fellow of BMJ Case Reports today and you can:

- Submit as many cases as you like

- Enjoy fast sympathetic peer review and rapid publication of accepted articles

- Access all the published articles

- Re-use any of the published material for personal use and teaching without further permission

For information on Institutional Fellowships contact consortiasales@bmjgroup.com

Visit casereports.bmj.com for more articles like this and to become a Fellow 